\title{
LEGISLATIVE ISSUES REGARDING PUBLIC POLICY DOCUMENTS IN THE MANAGEMENT OF LABOR MIGRATION. THE CASE OF THE REPUBLIC OF MOLDOVA
}

\author{
Mihail CEBOTARI \\ PHD Student, State University of Moldova, \\ Chișinău, Republica Moldova \\ e-mail: cebotari.mihai@gmail.com \\ https://orcid.org/0000-0002-1434-5128
}

\begin{abstract}
The present research is conducted in a field that is at the crossroads of the disciplines of labor law, migration, and administrative law. The article will reflect some of the aspects of labor migration policies and policy documents with which the author interacts in his current activity, but especially as a result of the ex-post evaluation of the Migration and Asylum Strategy (2011 - 2020) as a National Consultant for the International Organization for Migration. As we will argue, the impact and role of policies and policy documents in the field of labor migration is little researched both nationally and internationally, however as we will mention in this article the role of the policy framework is significant for the field of labor migration. Also regarding the issue of protection of migrants' rights, policy documents intervene in detail on aspects that are not regulated or are insufficiently covered by the current legal framework.
\end{abstract}

Keywords: policy documents, migration, labor migration, public administration, migrant protection.

\section{ASPECTE LEGISLATIVE PRIVIND DOCUMENTELE DE POLITICI PUBLICE ÎN GESTIONAREA MIGRAȚIEI DE MUNCĂ. CAZUL REPUBLICII MOLDOVA}

Prezentul articol este realizat într-un domeniu care se află la răscrucea disciplinelor de drept al muncii, migrațional și administrativ. În articol vor fi reflectate câteva dintre aspectele cu privire la politicile din domeniul migrației muncii și documentele de politici, cu care autorul interacționează în activitatea sa curentă, dar în special ca urmare a realizării evaluării ex-post a Strategiei Migrație și Azil (2011 - 2020) in calitate de Consultant Național pentru Organizația Internațională pentru Migrație. În opinia bint argumentată a autorului, impactul și rolul politicilor și documentelor de politici în domeniul migrației de muncă este puțin cercetat atât la nivel național cât și internațional, cu toate acestea in prezentul articol se menționează impactul acestui cadru de politici drept unul semnificativ pentru domeniul migrației muncii. De asemenea, pe aspectul protecției drepturilor migranților documentele de politici intervin detaliat pe aspecte care nu sunt reglementate, sau sunt insuficient acoperite de cadrul legal în vigoare.

Cuvintele-cheie: documente de politici, migrație, migrație de muncă, administrare publică, protecția migranților.

\section{ASPECTS LÉGISLATIFS CONCERNANT LES DOCUMENTS DE POLITIQUE PUBLIQUES DANS LA GESTION DE LA MIGRATION DE TRAVAIL. LE CAS DE LA REPUBLIQUE DE MOLDOVA}

La présente recherche est menée dans un domaine qui se situe au carrefour des disciplines du droit du travail, des migration et du droit administratif. L'article reflétera certains aspects concernant des politiques de migration de travail et des documents politiques avec lesquels l'auteur interagit dans son activité courant, mais surtout à la suite 
de l'évaluation ex-post de la Stratégie de Migration et d'Asile (2011 - 2020) en tant que consultant national pour le L'Organisation Internationale pour les Migrations. Comme nous le montrerons, l'impact et le rôle des politiques et des documents des politiques dans le domaine de la migration de travail font l'objet de peu de recherches, tant au niveau national qu'international. Aussi, en ce qui concerne la question de la protection des droits des migrants, les documents politiques interviennent en détail sur des questions qui ne sont pas réglementées ou sont insuffisamment couvertes par le cadre juridique actuel.

Mots-clés: documents des politiques, migration, migration de travail, administration publique, protection des migrants.

\section{ЗАКОНОДАТЕЛЬНЫЕ АСПЕКТЫ ДОКУМЕНТОВ ПУБЛИЧНЫХ ПОЛИТИК В УПРАВЛЕНИИ ТРУДОВОЙ МИГРАЦИЕЙ. ПРИМЕР РЕСПУБЛИКИ МОЛДОВА}

Данная статья представляет собой анализ области, находящейся на стыке дисииплин трудового, миграиионного и административного права. В статье отражены некоторые аспекты политик в области трудовой миграции и документов, с которыми автор взаимодействует в своей текущей работе, но особенно после оценки (ex-post) Стратегии Миграции и убежища на 2011-2020 годы в качестве национального консультанта Международной Организации по Миграџии. Согласно аргументированному мнению автора, существует мало исследований о влиянии и роли политик и документов публичных политик в области трудовой миграчии как на национальном, так и на международном уровне. Также, относительно вопроса защиты прав мигрантов, в документах публичных политик подробно рассматриваются вопросы, которые не регулируются или недостаточно охвачены действующей правовой базой.

Ключевые слова: документы публичных политик, миграчия, трудовая миграџия, публичная администраџия, защитта мигрантов.

\section{Introduction}

Research of public policies and policy documents in the field of labor migration by legal specialists is quite insignificant because as we will argue and show in this research, policy documents are not legal acts per se and do not contain legal norms. Yet, examining the case of the Republic of Moldova we will show that in practice policy documents contain and affect aspects related to labor migration which are not covered by the law. From this point of view we can say, that de facto, such policy documents are sources of law. This specific situation motivates us to research their impact from the perspective of legal disciplines.

Research methodology. Qualitative methodology is the main research tool used for the preparation of the present article. This also includes mostly a desk research activity for the documentation work.
An important source of information is the vast experience the author has as a National Consultant for various international organizations operating and interacting with the policy documents examined in the present paper. Also, the historic, logical, and comparative research methods were widely used.

\section{Definitions}

An initial analysis of the concepts examined in this article calls for the demarcation of the field of research by defining the terms "migration policy” and "policy document". Regarding the first definition we have to emphasize that according to some sources, the term immigration policy has not been defined in a rigorous and systematic manner [1, p. 558]. ,This is all the more important as so far hardly any systematic definitions have been provided. This lack of rigor, in turn, causes the first obstacle to policy-index building, as what is badly defined is 
likely to be badly measured" [1, op cit p. 558].

Another important aspect to be considered is the fact that much of the existing research on this topic is published in economically developed countries, which are mostly interested in immigration issues, and offer less importance to emigration which affects developing countries. These specifics together with the various international context on labor migration means that the approach to policies and policy documents is very different in the international arena, this also explains the absence of an international widely accepted definition of the term ,migration policy”.

Another important aspect that must be mentioned is that the concept of migration policy is general and includes both the legal documents as well as other public policy documents which define the policy of the state in the field of labor migration. For example, we can mention the definition of the term from a detailed article researching immigration policies: „we define immigration policy as: government's statements of what it intends to do or not do(including laws, regulations, decisions or orders) in regards to the selection, admission, settlement and deportation of foreign citizens residing in the country [1, op cit p. 559]. The authors of this detailed research emphasize the diversity of policies in these fields and the complexity of formulating a universal definition, therefore this study mentions that the provided definition is not absolute but mostly a call for discussing the concept.

Another similar definition is also based on a broad definition of migration policies as "rules (i.e., laws, regulations, and measures) that national states define and [enact] with the objective of affecting the volume, origin, direction, and internal composition of [...] migration flows" [2].

In the national legislation of Moldova, the definition of the concept of public policy can be found in the Government Decision Nr. 386/2020 approving the Regulation on the planning, elaboration, appro- val, implementation, monitoring, and evaluation of public policy documents. The point 3 of this Decision stipulates that: „Public policy is the coordinated decision or decisions of the state, which produce changes or influence society and the economy, contributing to solving problems and achieving the objectives assumed in a certain field of activity of the Government" [5].

The same Decision at point 4, defines the concept of Public Policy Document: „,The Public Policy Document describes the manner and resources needed to address the identified public policy issues, achieve development objectives in a particular field or subfield of Government activity and describes the expected impact on the state and society" [5]. This Government Decision is very clear on which type of document can be considered as a public policy document, stipulating at point 5 that there are only two types of policy documents in the Republic of Moldova: the strategy and the program.

We therefore can conclude some general aspects that characterize a policy document: 1 . It is not a normative act in the legal sense of the word. 2. It is rather a planning document that sets out a certain direction of activity and evolution for the authorities. 3. It is not mandatory for the authorities in the sense a legal norm is, failure to implement its provisions being subject to administrative control and monitoring by the responsible bodies.

\section{Historic evolution}

From a historic perspective, research on migration policies indicates that: „Over the 1945-2014 period, there has been an increase in the number of policy changes recorded. On one hand, this may partly reveal the difficulty in identifying migration policy changes in the earlier historical periods. On the other hand, this surely also reflects a real proliferation of migration policies, including their frequent adjustments. This growth is particularly noticeable 
between 1985-1989 and 1990-1994 when the number of policy changes recorded more than doubled, and a further major increase in 2000-2004. The introduction of complex migration policy packages targeting multiple objectives and migrant groups are bound to result in the rapid growth in the number of policy changes." The same study mentions that since 1945 across the 45 countries included in DEMIG POLICY. On average, 130 migration policy changes were recorded per country and for two-thirds of the countries, between 90 and 170 changes were tracked. The largest number of policy changes were recorded for Canada and France, as well as other countries with long immigration histories such as the United States and Australia or that play a crucial role as regional migration hub, such as Germany and Spain. The lowest number of policy changes were recorded for Czechoslovakia, Yugoslavia and the German Democratic Republic, reflecting the fact that these countries ceased to exist before migration became a phenomenon of great importance. Surprisingly, some countries with high migration volumes, such as Luxembourg and Israel, have relatively few migration policy changes [2].

From a chronological point of view in the Republic of Moldova, an initial comprehensive policy on migration was adopted in 2002, through the Government Decision Nr.1386/2002 on approving the Concept of migration policy of the Republic of Moldova [6]. This was the first initiative of the national authorities to adopt such a policy document. This was a very brief document encompassing around seven pages of text and correspondingly examining superficially many issues regarding labor migration. This concept included in the chapter on the priority directions of the migrational policy, many aspects regarding labor emigration or which impacted it, ex.: new modernized legal framework in this field, protection of migrants, reintegration of migrants, international cooperation with international bodies, and the need to adopt international conventions and sign agreements with destination countries for labor migration etc.

In 2011 through the Government Decision Nr.655/2011 the National Strategy on Migration and Asylum (2011-2020) was adopted [7]. This policy document was planned as a universal and general strategy covering the field of migration. As a policy document, it has content and structure which corresponds to the international practices in this field and has many similarities to the national Strategies on migration of other countries. This Strategy has as one of its main objectives the issues of emigration and reintegration of migrants. It proposes a detailed list of objectives and measures for implementation for both these fields. It is important to mention here that an obvious issue of this strategy is the absence of coherence between its objectives, measures of implementation, and indicators for implementation. This aspect makes it very difficult and even sometimes impossible to appreciate the impact of the Strategy after the end term of its implementation.

In the field of labor migration in the last decade, two sectoral strategies managed by the Ministry of Labor and Social Protection were implemented. Namely, the National strategy on employment policies for 2007-2015 [8] and the National employment strategy for the years 2017-2021 [9]. Much of the content of these Strategies include the aspects already stipulated and regulated in the National Strategy for Migration and Asylum 2011 - 2020. Also, the activities included in the action plans of these strategies are sometimes mirrored in the action plans for the implementation of the National Strategy for Migration and Asylum. This aspect contributes to a situation of implementation in the same time of similar activities by two national Strategies. While, apparently this can not be perceived as an issue, in reality, the existence of a separate Strategy, means that aspects such as reporting, monitoring, and in some cases co- 
ordination were separated from the General Strategy on Migration and Asylum (2011 - 2020). Therefore the implementation of the last-mentioned more complex Strategy did not take place in a whole, holistic manner, being fragmented between other Strategies implemented in the period $2011-2020$.

\section{Impact on labor migration and migrant workers}

An important and specific impact of the policy documents on the situation of migrant workers from the Republic of Moldova is the practical implementation through them of new concepts and even regulations that are not present in the general legal framework. We can provide at least three distinct examples when policy documents included new legal relations. An initial example would be the migration of high qualified migrants. While a general legal framework on the emigration of high-skilled migrants does not exist, general stipulations on the need to monitor and control this type of migration exist in the National Strategy on Migration and Asylum 2011 - 2020. A more detailed approach can be found in the Government Decision Nr. 452/2016 on the approval of the Strategy for the development of human resources in the health system for the years 2016-2025. This Strategy regulates in more detail aspects regarding the emigration of medical workers. The action plan for the implementation of this policy document has the specific objective Nr.21 which establishes and implements effective actions to manage the mobility of healthcare professionals. This objective includes four separate actions, some of them are: reintegration of returned migrant medical workers, creation of remote training platforms so that migrants can obtain medical studies while being abroad, etc. [10].

Other policy documents that regulate new relations are the action plans on supporting the reintegration of returned citizens from abroad. In the last decade two action plans on this topic were implemented, one in the period 2014 - 2016 [11] and another in the period 2017 - 2020 [12]. While the general legal framework of the Republic of Moldova does not include regulations on the reintegration of Moldovan emigrants returning to Moldova, these action plans have detailed measures and activities for this purpose. The 2014 - 2016 action plan, for example, provided for a contingency mechanism for the cases when a Moldovan emigrant is in a precarious situation abroad, this very ambitious action was not implemented. Another interesting action in the same action plan was to create a database for the registration of returned migrants. This was not achieved immediately but continued in the action plan for the period 2017 - 2020. Currently a monitoring mechanism exists, but only for those migrants which apply for certain governmental services on their return.

And finally, we need to mention the National Strategy "Diaspora-2025" and the Action Plan (2016-2018), for its implementation [13]. This policy document is important because it regulates and defines the term of diaspora. We can observe a difference in the term used in the Strategy and the one from the Government Decision Nr. 657/2009 [14]. The point 7 letter $\mathrm{j}^{1)}$ of the Decision Nr. 657/2009 defines diaspora as being, the citizens of the Republic of Moldova temporarily or permanently established abroad". While the Strategy Diaspora 2025 stipulates that it applies only to the persons who have moved abroad permanently and long-term migrants, while the indirect beneficiaries are members of their families from the Republic of Moldova. Here we observe that the policy Document applies to a narrower category of persons than that stipulated in the Government Decision 657/2009.

Also, this policy document stipulates, that it, together with the National Strategy on Migration and Asylum (2011 - 2020) ensures the elaboration and initiation of the implementation process by the Government of a comprehensive framework of secto- 
ral policies, to coordinate the areas associated with the migration process [13]. Therefore this Strategy is presented as a framework policy document in the field of migration, covering practically the majority of Moldovan emigrants. While we agree that the issues regarding diaspora need to have a leading role in the migration policy of the Republic of Moldova, we consider that a further and clearer definition of the terms „Diaspora”, as well as some basic legal norms serving as guidelines in this field should be adopted.

Even considering some of the above-mentioned issues, the impact of these strategies and action plans, was positive for the Moldovan migrant workers. The measures and mechanisms created and implemented by these policy documents covered problematic areas which sometimes needed quick intervention. But, speaking from a legal point of view, sometimes the questions of form can prevail over good intentions. For example, hypothetically a returned migrant could invoke in the national courts the action plans on reintegration because he could feel discriminated in the access for a certain procedure or services from the public bodies. A question arises in this case, will such a request be accepted, especially if the mechanisms to which the migrant is referring are included in a policy document? Many other similar situations could appear, which brings us to the conclusion on the need for a certain formal, legal regulation of some of the aspects included in public policy documents in the field of migration.

\section{Perspectives for a new framework of policy documents}

At this moment the ex-post evaluation of the National Strategy on Migration and Asylum (20112020) has been finished and the procedures for preparing a new framework policy document in the field of migration have been launched.

From the list of mentioned supra policy docu- ments only a few will continue to be implemented in the next decade, but it is not clear if they will be implemented to a finality. The Government decision Nr.386/2020 stipulates that all the documents which do not correspond to the conditions and requirements of this Decision have to be canceled in a two-year term from the adoption of this normative act [5]. This could potentially include the majority of policy documents in force at this moment. Also, this means that a new architecture of policy documents must be adopted.

In this context the Government Decision Nr.386/2020 institutes new types of policy documents. The Strategy is a long-term policy document for a $6-10$ years implementation period and which is adopted only for the fields of activity of the Government. Currently, the Law on Government Nr.136/2017 regulates at art.4 only 17 areas of activity, and also letter r) of the same article stipulates that other fields where the involvement of the government could be required can be considered. In the named supra 17 areas of activity, the field of migration is included at the letter o): demography, migration, and asylum [4]. The other type of policy document is the Program, which is a document for the implementation over a medium period of time (3-5 years). The Program is derived from the Strategy and subordinated to it, detailing the activities which must be realized in a specific field. The program includes a detailed action plan for the implementation of each action. At the implementation level, each state body has its annual action plan for the implementation of the relevant program.

We consider that a significant change and reformatting of the current policy framework will take place in the next period. But a change so systemic and important contributes to significant discussions and debates over the future architecture and general framework of policy documents. We consider that a separate Strategy in the migration field is necessary 
and that the demographic aspect has to be separated from it. This is because the migration field is vitally important for our country, and is very large in itself. Including the demography aspect, will complicate too much the implementation of a specialized Strategy in the field of migration. Such a Strategy will serve as the guiding template for the implementation of a range of programs covering all the fields of migration issues, including labor migration, reintegration of migrants, interaction with diaspora, etc.

The well-known authority in the field of migration studies, Stephen Castles mentions that: „the forces driving international migration are extremely complex and deeply embedded in general processes of social transformation. In turn, they interact with another complex set of forces in the processes of policy formation and implementation. It is not surprising that the results are often poorly conceived, narrow and contradictory policies, which may have unintended consequences. The very complexity of the factors involved makes any attempt at a general framework or theory impractical. However, this is not meant as a justification for resignation. It is essential for social scientists and policy-makers to examine the way these factors (and indeed others) interact in specific processes of migration and community formation, in order to achieve more balanced and realistic policies. Such analyses need to take account of certain crucial aspects of migration $[3, \mathrm{p}$. 222]".

We fully agree with this author and the necessity of a very well documented and scientifically planned work on a future framework of policy documents in the field of labor migration. We hope that this recommendation will be considered by national authorities and a multidisciplinary and well-informed team of scientists will be involved in the creation of the framework of policy documents in the field of migration and labor migration in particular.

\section{Conclusions}

1. In the actual regulatory field of labor migration in the Republic of Moldova policy documents play a significant role, regulating and intervening on aspects that are not covered by legislation, or that are covered insignificantly.

2. The significant influence of policy documents in the field of labor migration is due to several factors:

A. It is easier to regulate certain aspects regarding migration through policy documents because this permits avoiding the lengthy procedure of initiating and adopting legislative acts.

B. These types of regulations offer more flexibility to national authorities because they are not mandatory for implementation as the normative acts, therefore the consequences of not implementing a certain action from an action plan is in the worst case of an administrative nature.

C. They permit to regulate and intervene on a wider area of issues in this field.

3. The framework of policy documents in the last decade permitted the intervention of the state authorities in many fields which were not regulated by law, namely: reintegration of Moldovan migrants, interaction with diaspora, emigration of high skilled workers etc. This unorthodox approach permitted to the state authorities to intervene and protect migrant workers in situations that could not be possible otherwise.

\section{Recommendations}

1. It is necessary to ensure that the aspects covered in policy documents are regulated at least generally, at the concept level, in the national normative acts. The policy documents cannot serve as sources of law in themselves, because this aspect contravenes the basic principle of lawmaking. 
2. It is recommended to involve in the drafting of policy documents specialized legal professionals to ensure a holistic and professional approach regarding the creation and planning of policy documents.

3. A general Strategy in the field of migration is necessary for the next 6-10 years with specialized programs for the emigration aspect and the reintegration of returned migrants.

\section{Reference list}

\section{LIV BJERRE, MARC HELBLING, FRIEDERIKE} ROMER, MALISA ZOBEL. Conceptualizing and Measuring Immigration Policies: A Comparative Perspective. În: International Migration Review. 2015, Nr. 3, p. 555 600. Electronic ISSN 1747-7379.

2. HEIN DE HAAS, KATHARINA NATTER, SIMONA VEZZOLI. Conceptualizing and measuring migration policy change [online]. În: Comparative Migration Studies. 2015, Vol 3, [citat 21.12.2021]. Disponibil: https://comparativemigrationstudies.springeropen.com/ articles/10.1186/s40878-015-0016-5.

3. STEPHEN CASTLES. Why migration policies fail. În: Ethnic and Racial Studies. 2004, Nr.2, p. 205-227. ISSN 1466-4356.

4. Lege Cu privire la Guvern, Nr. 136 din 07.07.2017, În: Monitorul Oficial Nr. 252 art. 412.

5. Hotărâre cu privire la planificarea, elaborarea, aprobarea, implementarea, monitorizarea și evaluarea documentelor de politici publice, Nr. 386 din 17.06.2020. În: Monitorul Oficial Nr. 153-158 art. 509.

6. Hotărâre privind aprobarea Concepţiei politicii mi- graționale a Republicii Moldova Nr. 1386 din 11.10.2002. In: Monitorul Oficial Nr. 146-148 art. 1140.

7. Hotărâre cu privire la aprobarea Strategiei naţionale în domeniul migraţiei şi azilului (2011-2020) Nr. 655 din 08.09.2011. În: Monitorul Oficial Nr. 152-155 art. 726.

8. Hotărâre Nr. 605 din 31-05-2007 pentru aprobarea Strategiei naţionale privind politicile de ocupare a forţei de muncă pe anii 2007-2015. În: Monitorul Oficial Nr. 82-85 art. 660 .

9. Hotărâre cu privire la aprobarea Strategiei naţionale privind ocuparea forţei de muncă pentru anii 2017-2021, Nr. 1473 din 30-12-2016. În: Monitorul Oficial Nr. 109118 art. 272.

10. Hotărâre cu privire la aprobarea Strategiei de dezvoltare a resurselor umane din sistemul sănătăţii pentru anii 2016-2025, Nr. 452 din 15.04.2016. În: Monitorul Oficial Nr. 106-113 art. 506.

11. Hotărâre Nr. 339 din 20.05.2014, cu privire la aprobarea Planului de acţiuni pentru anii 2014-2016 privind susţinerea reintegrării cetăţenilor reîntorşi de peste hotare, Publicat: 30.05.2014 în Monitorul Oficial Nr. 134141, art Nr: 381.

12. Hotărâre cu privire la aprobarea Planului de acțiuni pentru anii 2017-2020 privind (re)integrarea cetățenilor Republicii Moldova reîntorși de peste hotare, Nr. 724 din 08.09.2017. În: Monitorul Oficial Nr. 335-339 art. 828.

13. Hotărâre cu privire la aprobarea Strategiei naţionale „Diaspora-2025” şi a Planului de acţiuni pentru anii 2016-2018 privind implementarea acesteia, Nr. 200 din 26.02.2016. În: Monitorul Oficial Nr. 49-54 art. 230.

14. Hotărâre pentru aprobarea Regulamentului privind organizarea şi funcţionarea, structurii şi efectivului-limită ale Cancelariei de Stat, Nr. 657 din 06.11.2009. În: Monitorul Oficial Nr. 162 art. 724. 